\title{
慢性関節リウマチにおける股関節破壊の検討
}

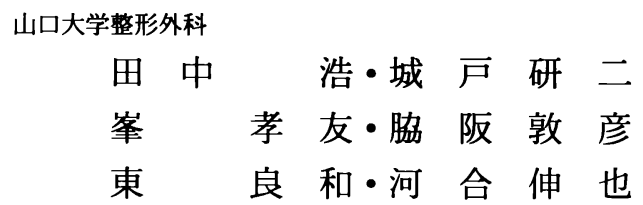

\section{Studies of Hip Disease in Rheumatoid Arthritis}

\author{
Hiroshi Tanaka, Kenji Kido, Takatomo Mine, Atsuhiko Wakisaka, \\ Yoshikazu Azuma, and Sinya Kawai \\ Department of Orthopedic Surgery School of Medicine, Yamaguchi University, Ube
}

\begin{abstract}
Hip radiographs were examined in forty patients with rheumatoid arthritis who had total hip arthroplasties. The patients' ages ranged from 37 to 83 years.

Radiological appearances of hip involvement was calssified into five types as described by Lowe et al. Radiographic evaluation showed that protrusio acetabuli and loss of joint space were seen in $45 \%$ and $28 \%$, respectively. Types of hip involvement correlated with the serum level of CRP and type of joint destruction (LES, MES, MUD), but not with disease duration, maintenance dose of corticosteroids and JOA score. $70 \%$ of the patients with protrusio acetabuli were MUD type and most with loss of joint space were LES or MES type.
\end{abstract}

Key words : Rheumatoid Arthritis (慢性関節リウマチ), Roentogenology (X線学)

はじめに

RA において股関節が侵される頻度は比較的少ない が, 滑膜炎の他, 骨粗箖, 荷重等の要因も関与し多彩 な病像を呈する. 今回 THA を施行した症例を対象之 して, RA の病像, 経過および股関節破壊のパターン について検討した.

\section{対象および方法}

対象は, RA に対してTHA を施行した症例, 40 例 52 関節で, 性別は, 女性 38 例, 男性 2 例で, 手術時 年齢は, 平均 59.8 才であった.これらの症例に対し, $\mathrm{RA}$ の雉病期間, 股関節痛の出現時期, リウマチの活 動性, 関節破壊のタイプ, および, 日整会变股症判定 基準による臨床評価について調查した，股関節破壊の

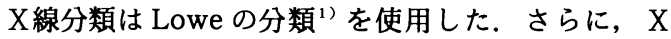
線分類と他の因子との相関について検討した.

\section{結果}

RA の分類は，ステージ 3 および 4 が約半数ずつで あり, クラス 3 が半数以上にみられた。 また，ムチラ ンス型および多関節破壊型の関節破壊がほぼ同数であっ た. RA の罹病期間は, 平均 18.2 年と長期経過例が 多く見られたが，股関節痛出現よりTHA までの期間 は, 平均 2 年であり, 比較的短期間に関節破壊が進行 していた，血液検査所見では，炎症自体は比較的落ち 着いた例が多く見られた。 ステロイドは約 7 割に使用 されており, 平均使用量は $3 \mathrm{mg}$ であった，臨床評価 としての日整会点数は, 35 点で, 特に歩行能力が著 明に障害されていた．X線所見は，Lowe の分類を使 


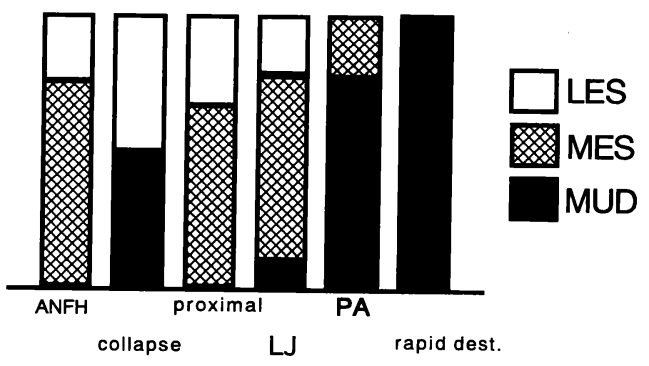

図 $1 \mathrm{X}$ 線分類と病型分類との関連

LJ は，少および多関節破壊型，PA は，ムチランス 型に多くみられた。

用し分類したが，破壊が内方ではなく上方のみに進行 するタイプがみられ，これを新たに proximal type とし，また, collapse of femoral headのうち, RA 様の変化がみられず明らかに大腿骨頭壊死の所見を呈 するすのを aseptic necrosis として別に追加した，X 線分類の比率は, protrusio acetabuli (以下 PA）お よび loss of joint space（以下 LJ）がそれぞれ 45\%,

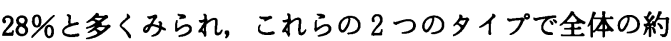
7 割を占めていた。 また, PA タイプの protrusion distance は, 1 から $15 \mathrm{~mm}$, 平均 $5.1 \mathrm{~mm}$ であった. $\mathrm{X}$ 線分類と病型分類との関連についてみると，PA, Charcot-type joint はほとんどムチランス型であり， LJ は，半数以上を多関節破壊型が占めていた，X線 分類と各因子との関連についてみると，PA は LJ に 比べ，CRP が有意に低く，リウマチ因子も低い傾向 がみられた．また，有意な差はないものの，PAに， RA の䍜病期間や股関節痛から THA までの期間が長 く, ステロイド使用量が多い傾向がみられた.

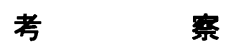

$\mathrm{RA}$ における股関節破壊のX線分類についてこれま でに様々な報告 ${ }^{2)-4)}$ がなされてきたが，今回，簡単 に股関節破壊の過程にみられる特徴を列挙した Lowe の分類を使用した。一般的に RA において股関節が 侵される頻度は, 約 $20 \%$ 前後で, それらのうち PA
となる頻度は, 約 15\%であるが(1)4, THA の症例で は, やはり頻度が高くなり ${ }^{2)}$, 今回の調查においても 45\%にみられた．PA と LJ の比較検討では, PA は ムチランス型，LJは少および多関節破壊型に多くみ られた。 また, PA は LJに比べ, RA の活動性が低 い傾向がみられたが，これは，PA の症例が， RA の 罹病期間が比較的長く burn out したようなものが多 いことによると考える.PA となれば，手術も困難と なり，手術成績 不良で, 諸家が指摘するようにここ まで進展する前に手術をすべきである．しかしながら， 現実では，今回の結果のようにPAに至って手術とな ることが多く,これには，重症の RA では，ADLの 低下や，他の関節痛のため，LJ の時期に股関節痛を 自覚しにくく, 結果としてTHA のタイミングの遅れ が考えられる. 今後は，LJ から PA へ至る過程の詳 細な観察や，進展を予測する因子についての検討が必 要であると考える.

\section{ま と め}

1） RA40 例 52 関節に対し股関節破壊のパターン について検討した.

2) PA およびLJ がそれぞれ $45 \% ， 28 \%$ と多くみ られた.

3）LJ は少および多関節破壊型, PA はムチラン ス型に多くみられた。

4) PA は LJ に比へ， RA の活動性が低く, RA の 䍜病期間, 股関節痛から THA までの期間が長い傾向 がみられた。

\section{参考 文 献}

1) Glick, E. N. et al. : Rheumatoid arthritis affecting the hip joint. Ann. Rheu. Dis., 22 : 416-423, 1963.

2）勝部定信 : 慢性関節リウマチにおける股関節の $X$ 線学 的ならびに組織学的研究. 日整会誌, $64: 378-391$, 1990.

3) Lowe, L. W. : Surgery of the Hip Joint. Lea \& febriger, Philadelphia, 597-609, 1973.

4）種田陽一，他：慢性関節リウマチの股関節病変の自然 経過．関節外科， $8: 1301-1308 ， 1989$. 